\title{
Gambogic acid potentiates the chemosensitivity of colorectal cancer cells to 5-fluorouracil by inhibiting proliferation and inducing apoptosis
}

\author{
JIANCHANG WEI $^{1 *}$, PING YANG $^{1 *}$, WANGLIN LI ${ }^{1}$, FENG HE $^{1}$, SHANQI ZENG ${ }^{1}$, \\ TONG ZHANG ${ }^{1}$, JUNBIN ZHONG ${ }^{1}$, DI HUANG ${ }^{1}$, ZHUANPENG CHEN $^{1}$, \\ CHENGXING WANG ${ }^{1,2}$, HUACUI CHEN ${ }^{1}, \mathrm{HE} \mathrm{HU}^{1}$ and JIE CAO ${ }^{1}$
}

\begin{abstract}
${ }^{1}$ Department of General Surgery, Guangzhou Digestive Disease Center, Guangzhou First People's Hospital, Guangzhou Medical University, Guangzhou, Guangdong 510180; ${ }^{2}$ Department of Gastrointestinal Surgery, Affiliated Jiangmen Hospital of Sun Yat-sen University, Jiangmen, Guangdong 529000, P.R. China
\end{abstract}

Received December 2, 2015; Accepted May 20, 2016

DOI: $10.3892 / \mathrm{etm} .2017 .4021$

\begin{abstract}
Chemotherapy using 5-fluorouracil (5-FU) for colorectal cancer (CRC) has low specificity and response rates, leading to severe side effects. Gambogic acid (GA), a traditional Chinese medicine, has multi-targeted anticancer effects, including growth inhibition and apoptosis induction. However, it is unclear whether a combination of 5-FU and GA has synergistic anticancer effects in CRC cells. In this study, SW480 and HCT116 human CRC cells and human intestinal epithelial cells (IECs) were treated with different concentrations of 5-FU, GA or 5-FU+GA. A Cell Counting kit-8 assay was conducted to quantify cell proliferation. The combination index (CI) was calculated and the median-effect principle was applied to analyze the interaction between 5-FU and GA. Flow cytometry was used to determine the percentage of cells undergoing apoptosis. Reverse transcription-quantitative polymerase chain reaction and western blotting were applied to measure P53, survivin and thymidylate synthase (TS) mRNA and protein levels. It was found that 5-FU+GA more pronouncedly inhibited cell growth and induced apoptosis, compared with either monotherapy. CI values $<1$ indicated the synergistic effects of the drugs. 5-FU+GA further decreased
\end{abstract}

Correspondence to: Professor Jie Cao, Department of General Surgery, Guangzhou Digestive Disease Center, Guangzhou First People's Hospital, Guangzhou Medical University, 1 Panfu Road, Guangzhou, Guangdong 510180, P.R. China

E-mail: czhongt@126.com

*Contributed equally

Abbreviations: 5-FU, 5-fluorouracil; CRC, colorectal cancer; GA, gambogic acid; CI, combination index; TS, thymidylate synthase; IEC, intestinal epithelial cell

Key words: gambogic acid, 5-fluorouracil, colorectal cancer, chemosensitivity, apoptosis
P53, survivin and TS mRNA and protein levels in the two CRC cell lines compared with single drugs, whereas increased P53 protein levels were observed in HCT116 cells. Moreover, 5-FU+GA did not increase cytotoxicity to IECs. These results demonstrate that GA enhances the anticancer effects of 5-FU on CRC cells. Combined treatment with 5-FU and GA is effective and safe for CRC cells, and may become a promising chemotherapy treatment.

\section{Introduction}

Colorectal cancer (CRC) is one of the most commonly diagnosed malignancies and a leading cause of cancer-related mortality worldwide (1). China has a high incidence of CRC; with 149,722 estimated mortalities in 2011, it represents one-fifth of all cancers in terms of both morbidity and mortality (2).

Treatment options for CRC include surgery, chemotherapy and radiotherapy. Surgical resection is the main and most effective option (3). However, surgery alone is insufficient to treat CRC, and certain patients do not have the opportunity to undergo surgical treatment (4). Systemic chemotherapy is an important tool, particularly for patients with advanced CRC: it can decrease clinical symptoms, improve the quality of life, and prolong survival (5).

5-Fluorouracil (5-FU)-based chemotherapeutics are commonly used in CRC (6), with a single drug response rate of $\sim 21 \%$ (7). Clinicians have used oxaliplatin (4) or irinotecan (8) in combination with 5-FU to enhance chemotherapeutic effects, but have only obtained response rates of $30-50 \%$ (4). In addition, these drugs have low specificity; although they increase 5-FU activity, they also promote damage to normal cells, and side effects are prominent (9).

Therefore, the development of novel chemotherapy strategies is essential. Several studies (10-12) have shown that combining chemotherapeutics with traditional Chinese medicine can result in cooperative effects and enable the required doses of chemotherapeutics to be reduced, resulting in lower drug toxicity, decreased side effects and reduced drug 
resistance. This has become a topic of particular research interest in cancer treatment.

Gambogic acid (GA), a common traditional Chinese medicine and the main active component of Garcinia hanburyi, has limited side effects (13). Previous studies have shown that GA has multi-targeted antitumor effects, including inhibition of proliferation (14), induction of apoptosis (15), cell cycle arrest (16), and inhibition of angiogenesis (17), invasion and metastasis (18).

P53 is a key tumor suppressor (19); it induces apoptosis, which is one of the mechanisms that stop cancer cells from growing (20). Survivin, the smallest member of the inhibitor of apoptosis (IAP) family (21), is known to be a key regulator in cancer proliferation and apoptosis (22). The overexpression of survivin has been found to be associated with a poor prognosis (23) and chemoresistance (24). Thymidylate synthase (TS) is a key enzyme in 5-FU metabolism (25) and has been shown to function as an oncogene (26). 5-FU exerts cytotoxicity by inhibiting TS activity and interrupting DNA and RNA syntheses (27). High TS expression is also associated with 5-FU resistance (28) and poor prognosis (29).

So far, to the best of our knowledge, whether GA enhances 5-FU chemotherapy in CRC has not been investigated. In the present study, the effects of 5-FU combined with GA were evaluated in two CRC cell lines, and the effects of the combination on the regulation of P53, survivin and TS, apoptosis and chemoresistance-related genes were explored.

\section{Materials and methods}

Materials. SW480 and HCT116 cells were obtained from American Type Culture Collection (ATCC; Manassas, VA, USA), and cultured in RPMI-1640 (Gibco; Thermo Fisher Scientific, Inc., Waltham, MA, USA) supplemented with $10 \%$ fetal bovine serum (FBS; Thermo Fisher Scientific, Inc.) at $37^{\circ} \mathrm{C}$ with $5 \% \mathrm{CO}_{2}$. Human intestinal epithelial cells (IECs) were purchased from ATCC and cultured in Dulbecco's modified Eagle's medium (Gibco; Thermo Fisher Scientific, Inc.) containing $10 \% \mathrm{FBS}$ at $37^{\circ} \mathrm{C}$ with $5 \% \mathrm{CO}_{2}$. GA was obtained from Sigma-Aldrich (St. Louis, MO, USA); 5-FU was purchased from Shanghai Xudong Haipu Pharmaceutical Co., Ltd. (Shanghai, China; H31020593). Cell counting kit-8 (CCK-8; C0037) was obtained from Beyotime Institute of Biotechnology (Haimen, China). Alexa Fluor ${ }^{\circledR} 488$ Annexin V/Dead Cell Apoptosis kit (V13245) was from Invitrogen (Thermo Fisher Scientific, Inc.). The antibodies against P53 (ab131442; rabbit polyclonal, $53 \mathrm{kDa}$ ), survivin (ab24479; rabbit monoclonal, $16 \mathrm{kDa}$ ), thymidylate synthase (ab3145; mouse monoclonal, $35 \mathrm{kDa}$ ) and $\beta$-actin (ab6276; mouse monoclonal, $42 \mathrm{kDa}$ ) were from Abcam (Cambridge, MA, USA).

Cell proliferation assay. SW480 or HCT116 cells, or IECs $\left(4 \times 10^{4}\right.$ cells $\left./ \mathrm{ml}\right)$ were seeded in 96 -well plates and cultured overnight. Solutions (100 $\mu \mathrm{l})$ containing different concentrations of GA $(0,0.25,0.5,0.75,1,1.5,2$ and $3 \mu \mathrm{M}), 5-\mathrm{FU}(0$, $6.25,12.5,25,50,100$ and $200 \mu \mathrm{M})$ or 5 -FU+GA were added for $48 \mathrm{~h}$. Afterwards, $10 \mu \mathrm{l}$ CCK-8 solution was added to each well, and the absorbance at $450 \mathrm{~nm}$ was read using a microplate reader (iMark; Bio-Rad Laboratories, Inc., Hercules, CA,
USA) after $2 \mathrm{~h}$ of incubation. All assays were carried out in triplicate.

Combined effect analysis. The interactions of the two drugs were evaluated by the median-effect principle, using the combination index (CI) method (30). CI values of 5-FU and GA were calculated using CompuSyn (USA) software (ComboSyn, Inc., Paramus, NJ, USA) where $\mathrm{CI}<1, \mathrm{CI}=1$ and $\mathrm{CI}>1$ indicate synergism, addition and antagonism, respectively.

Morphological observations. SW480 or HCT116 cells were cultured in $25-\mathrm{cm}^{2}$ flasks to approximately $\sim 80 \%$ confluency, and 5-FU (SW480, $122.14 \mu \mathrm{M}$; HCT116, $18.43 \mu \mathrm{M}$ ), GA (SW480,0.75 $\mu \mathrm{M}$; HCT116, $1 \mu \mathrm{M}$ ) and 5-FU+GA, respectively, were added for $48 \mathrm{~h}$. After three washes, cells were assessed using an inverted optical microscope.

Assessment of cell apoptosis. Cells were harvested after $48 \mathrm{~h}$ incubation with GA, 5-FU or 5-FU+GA, and resuspended in Annexin-binding buffer to $2 \times 10^{6}$ cells $/ \mathrm{ml}$. Annexin $\mathrm{V}$ and propidium iodide (PI) working solutions were added and the cells were incubated at room temperature for $15 \mathrm{~min}$. Flow cytometry was performed (BD Biosciences, Franklin Lakes, NJ, USA), and data were analyzed using FlowJo 7.6 software (FlowJo, LLC, Ashland, OR, USA). All assays were run in triplicate.

Reverse transcription-quantitative polymerase chain reaction (RT-qPCR). Total RNA was extracted from the cells using Tripure isolation reagent (Roche Applied Science, Basel, Switzerland), and RNA samples were treated with DNase (Ambion; Thermo Fisher Scientific, Inc.). cDNA was synthesized from the obtained RNA samples using the Primescript 1st strand cDNA Synthesis kit (6110A; Takara Bio, Inc., Otsu, Japan) according to the manufacturer's protocol. Primers were designed using Primer Premier 6.0 software (Premier Biosoft, Palo Alto, CA, USA) and synthesized by Guangzhou Dahui Biotech Co., Ltd. (Guangzhou, China), with the following sequences (5' to 3 '): Glyceraldehyde 3-phosphate dehydrogenase (GAPDH; amplicon size, 164 bp), forward: TCCACTGGCGTCTTCACCACCAT and reverse: GGAGGCATTGCTGATGATCTTGAGG; P53 (amplicon size, $101 \mathrm{bp}$ ), forward: TGTTGGTCGGTGGGT TGGTAGT and reverse: GAGGTTGTCAGACAGGGT TTGGC; survivin (amplicon size, $133 \mathrm{bp}$ ), forward: AGC CCTTTCTCAAGGACCACCG and reverse: GCCAAGTCT GGCTCGTTCTCAG; TS (amplicon size, $101 \mathrm{bp}$ ), forward: CCATGCCCTCTGCCAGTTCTATG and reverse: TGGCGATGTTGAAAGGCACACC. qPCR was carried out using a SYBR Green Realtime PCR Master Mix kit [E090; Novo Protein Scientific (Shanghai), Inc., Shanghai, China] with a reaction mixture containing $2 \mu \mathrm{l}$ cDNA, $0.25 \mu \mathrm{l}$ each primer and $10 \mu \mathrm{lSYBR}$ Green at $95^{\circ} \mathrm{C}(5 \mathrm{~min})$ followed by 45 cycles of $95^{\circ} \mathrm{C}(10 \mathrm{sec})$ and $60^{\circ} \mathrm{C}(30 \mathrm{sec})$. All assays were run in triplicate. CT values were assessed using IQ5 software (Bio-Rad Laboratories, Inc.). Relative expression of target genes was determined using the $2^{-\Delta \Delta \mathrm{Cq}}$ method (31).

Western blot analysis. Total protein was extracted from the cells with SDS-PAGE protein sample buffer (Beyotime Institute of Biotechnology, Haimen, China), resolved by SDS-PAGE 

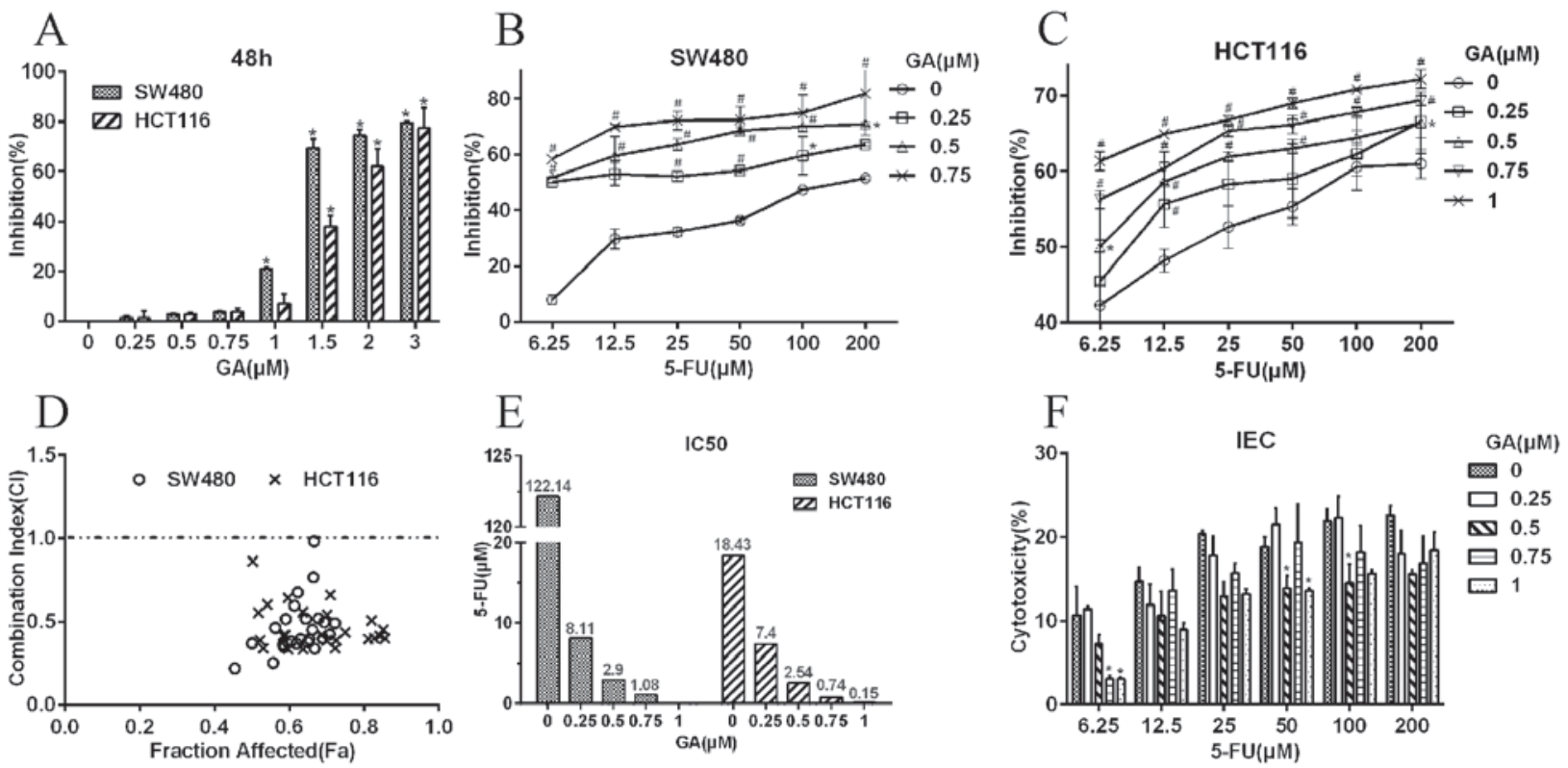

Figure 1. Effects of 5-FU combined with GA. (A) Inhibitory effects of various GA concentrations on SW480 and HCT116 cells at 48 h. ${ }^{*} \mathrm{P}<0.05$ vs. control $(0 \mu \mathrm{M})$. (B and C) Combined effects of GA and 5-FU on (B) SW480 and (C) HCT116 cells. Cells were co-exposed to different concentrations of 5-FU and non-inhibitory concentrations of GA for $48 \mathrm{~h}$. "P<0.05 and ${ }^{\#} \mathrm{P}<0.01$ vs. 5-FU alone. (D) Combination index (CI) plot for GA+5-FU treatment. The points below the line indicate $\mathrm{CI}<1$. (E) $\mathrm{IC}_{50}$ values of 5-FU when combined with GA at different concentrations. (F) Cytotoxicity of 5-FU+GA on IECs at $48 \mathrm{~h}$. ${ }^{*} \mathrm{P}<0.05$ vs. 5-FU alone. All assays were run in triplicate. 5-FU, 5-fluorouracil; GA, gambogic acid; $\mathrm{IC}_{50}, 50 \%$ cell growth inhibitory concentration; IEC, intestinal epithelial cell.

(concentration gel, 5\%; separation gel, 10\%) and transferred onto polyvinylidene fluoride membranes. After blocking with $5 \%$ non-fat milk, membranes were incubated with anti-P53 $(1: 1,000)$, anti-survivin $(1: 1,000)$, anti-TS $(1: 100)$ and anti- $\beta$-actin $(1: 5,000)$ antibodies at $4{ }^{\circ} \mathrm{C}$ overnight. This was followed by incubation with goat anti-rabbit antibody (1:10,000; SA00001-2;) or goat anti-mouse antibody (1:10,000; SA00001-1; both Wuhan Sanying, Biotechnology, Wuhan, China) at room temperature for $1 \mathrm{~h}$. Signals were visualized with the SuperSignal West PICO chemiluminescent detection system (Pierce; Thermo Fisher Scientific, Inc.). Protein bands were detected using Quantity One version 4.62 software (Bio-Rad Laboratories, Inc.) and relative protein levels were calculated based on $\beta$-actin protein. All assays were run in triplicate.

Statistical analysis. Data are presented as the mean \pm standard deviation. Comparisons were performed by one-way analysis of variance using SPSS version 21.0 software (IBM SPSS, Armonk, NY, USA). $\mathrm{P}<0.05$ was considered to indicate a statistically significant difference.

\section{Results}

5-FU and GA display synergistic inhibitory effects. As shown in Fig. 1A, GA at $0.25,0.5$ and $0.75 \mu \mathrm{M}$ did not inhibit the proliferation of SW480 cells, and at $0.25,0.5,0.75$ and $1 \mu \mathrm{M}$ did not inhibit the proliferation of HCT116 cells $(\mathrm{P}>0.05)$. However, GA at higher concentrations inhibited cell growth in a concentration-dependent manner $(\mathrm{P}<0.05)$. To avoid the inhibitory effects of GA, non-inhibitory GA concentrations were selected for further combination experiments, that is, 0.25 , 0.5 and $0.75 \mu \mathrm{M}$ for SW480 cells and $0.25,0.5,0.75$ and $1 \mu \mathrm{M}$ for HCT116 cells.
Notably, 5-FU+GA exhibited a more pronounced inhibitory effect compared with 5-FU monotherapy (Fig. 1B and C). The inhibitory effects increased as the GA concentration in the combination increased, indicating that GA enhanced 5-FU-induced inhibition in a concentration-dependent manner $(\mathrm{P}<0.05)$.

All CI values were $<1$ for treatment with $5-\mathrm{FU}(6.25,12.5$, $25,50,100$ and $200 \mu \mathrm{M})$ combined with GA $(0.25,0.5$ and $0.75 \mu \mathrm{M}$ for SW480 cells; $0.25,0.5,0.75$ and $1 \mu \mathrm{M}$ for HCT116 cells) at $48 \mathrm{~h}$, suggesting that the two drugs in these concentrations function synergistically (Fig. 1D).

Based on the above data, the $50 \%$ cell growth inhibitory concentrations ( $\mathrm{IC}_{50}$ values) of 5-FU were calculated (Fig. 1E). The $\mathrm{IC}_{50}$ decreased with increasing concentration of GA in the combination, which directly demonstrated that GA enhanced the sensitivity to 5-FU of SW480 and HCT116 cells, in a concentration-dependent manner.

As GA was able to potentiate 5-FU cytotoxicity in cancer cells, whether 5-FU+GA affects normal cells in a similar manner was further investigated. As shown in Fig. 1F, no significant increase in cytotoxicity was observed. Instead, GA decreased the cytotoxicity of 5-FU in IECs $(\mathrm{P}<0.05)$.

To further explore these effects of 5-FU+GA, maximum non-inhibitory GA concentrations were selected in subsequent experiments, that is, $0.75 \mu \mathrm{M}$ for SW480 cells and $1 \mu \mathrm{M}$ for HCT116 cells. $\mathrm{IC}_{50}$ values were selected as the 5-FU concentrations, that is, 122.14 and $18.43 \mu \mathrm{M}$ for SW480 and HCT116 cells, respectively.

Morphological changes of cells. SW480 and HCT116 cells in the control group were adherent, with clear bar-shaped outlines, and good refraction. Following treatment with GA for $48 \mathrm{~h}$, cell numbers decreased and cell gaps widened. In 

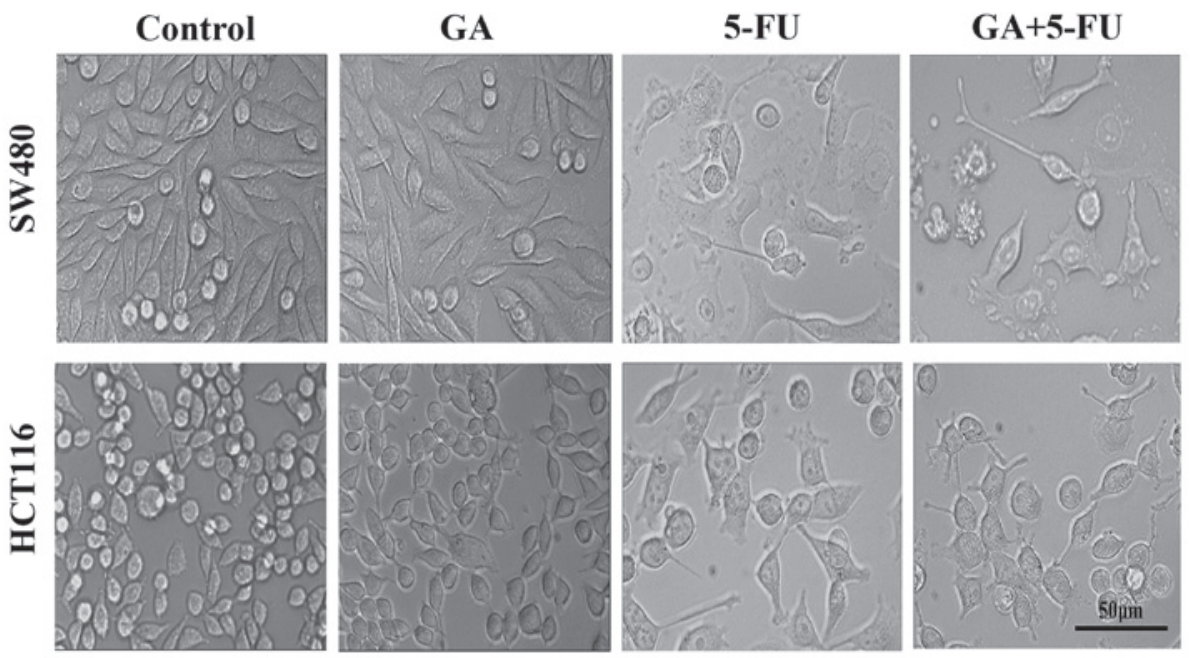

Figure 2. Morphological changes in cells treated with 5-FU, GA or 5-FU+GA. Cells were treated with GA (SW480, $0.75 \mu \mathrm{M} ; \mathrm{HCT116,} 1 \mu \mathrm{M}$ ), 5-FU (SW480, $122.14 \mu \mathrm{M} ; \mathrm{HCT} 116,18.43 \mu \mathrm{M}$ ) or GA+5-FU for $48 \mathrm{~h}$. Untreated cells were used as controls. 5-FU, 5-fluorouracil; GA, gambogic acid.
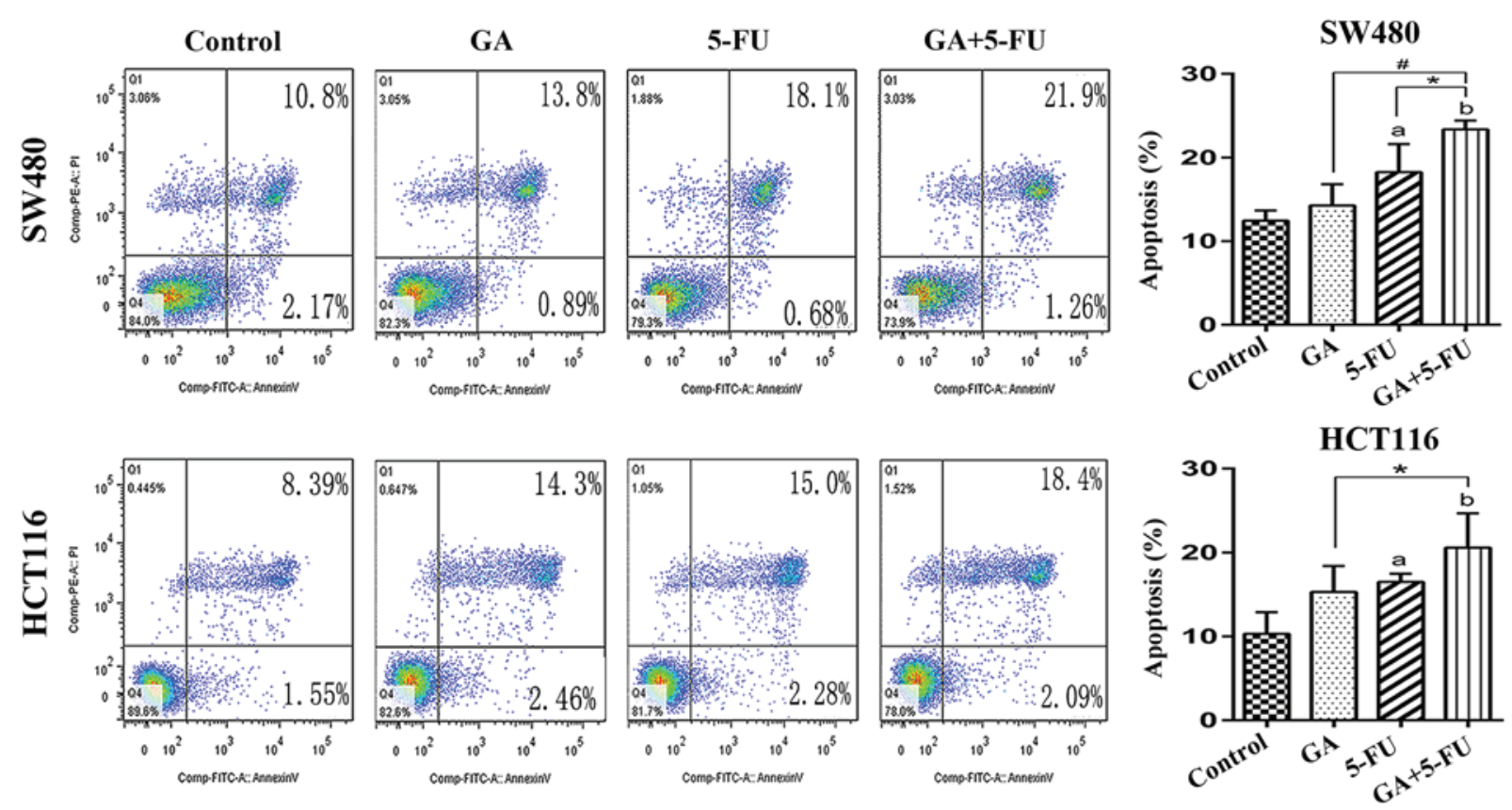

Figure 3. Apoptosis in cells treated with 5-FU, GA or 5-FU+GA. Cells were treated with GA (SW480, $0.75 \mu \mathrm{M} ; \mathrm{HCT116,1} \mu \mathrm{M}$ ), 5-FU (SW480, 122.14 $\mu \mathrm{M}$; HCT116, $18.43 \mu \mathrm{M})$ or $\mathrm{GA}+5-\mathrm{FU}$ for $48 \mathrm{~h}$. Untreated cells were used as controls. ${ }^{\mathrm{a}} \mathrm{P}<0.05$ and ${ }^{\mathrm{b}} \mathrm{P}<0.01$ vs. the control. ${ }^{*} \mathrm{P}<0.05$ and ${ }^{~} \mathrm{P}<0.01$. All assays were run in triplicate. 5-FU, 5-fluorouracil; GA, gambogic acid; PE, phytoerythrin; PI, propidium iodide; FITC, fluorescein isothiocyanate.

the 5-FU group, cell numbers decreased greatly; cells became round with shrunken bodies and obscure outlines. The effects were more pronounced in the combination group (Fig. 2).

GA enhances 5-FU-induced apoptosis. Apoptosis rates were increased in SW480 and HCT116 cells treated with 5-FU alone for $48 \mathrm{~h}$ compared with the respective control values $(\mathrm{P}<0.05)$; the combination yielded stronger effects compared with 5-FU or GA alone $(\mathrm{P}<0.05)$. These findings indicate that the synergistic inhibition of 5-FU+GA partly resulted from increased apoptosis (Fig. 3).

Effects on P53, survivin and TS mRNA levels. To further explore the synergistic effects of 5-FU and GA, P53, survivin and TS mRNA expression levels were examined. 5-FU alone decreased P53, survivin and TS mRNA levels in SW480 cells compared with those in the control group; it also decreased P53 and TS mRNA levels in HCT116 cells $(\mathrm{P}<0.01)$. GA alone decreased survivin mRNA levels in SW480 cells and decreased P53, survivin and TS mRNA levels in HCT116 cells $(\mathrm{P}<0.05)$. The effects of the combination were more pronounced in both SW480 and HCT116 cells compared with the effects of 5-FU or GA alone ( $\mathrm{P}<0.05$; Fig. 4).

Effects on P53, survivin and TS protein levels. Compared with control group levels, 5-FU alone decreased P53, survivin and TS protein levels in SW480 cells, whereas in HCT116 cells 5-FU alone increased P53 protein levels and decreased 
SW480

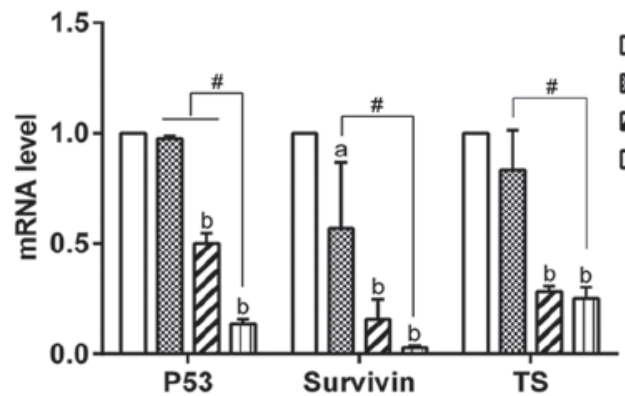

HCT116

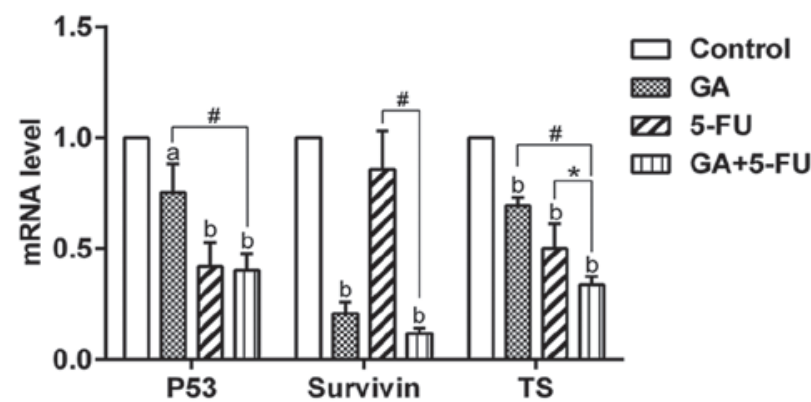

Figure 4. Changes of P53, survivin and TS mRNA levels. Cells were treated with GA (SW480, 0.75 $\mu \mathrm{M} ; \mathrm{HCT} 116,1 \mu \mathrm{M}), 5$-FU (SW480, 122.14 $\mu \mathrm{M}$; HCT116, $18.43 \mu \mathrm{M})$ or $\mathrm{GA}+5-\mathrm{FU}$ for $48 \mathrm{~h}$. Untreated cells were used as controls. ${ }^{\mathrm{a}} \mathrm{P}<0.05$ and ${ }^{\mathrm{b}} \mathrm{P}<0.01$ vs. the control. * $\mathrm{P}<0.05$ and ${ }^{\#} \mathrm{P}<0.01$. All assays were run in triplicate. 5-FU, 5-fluorouracil; GA, gambogic acid.
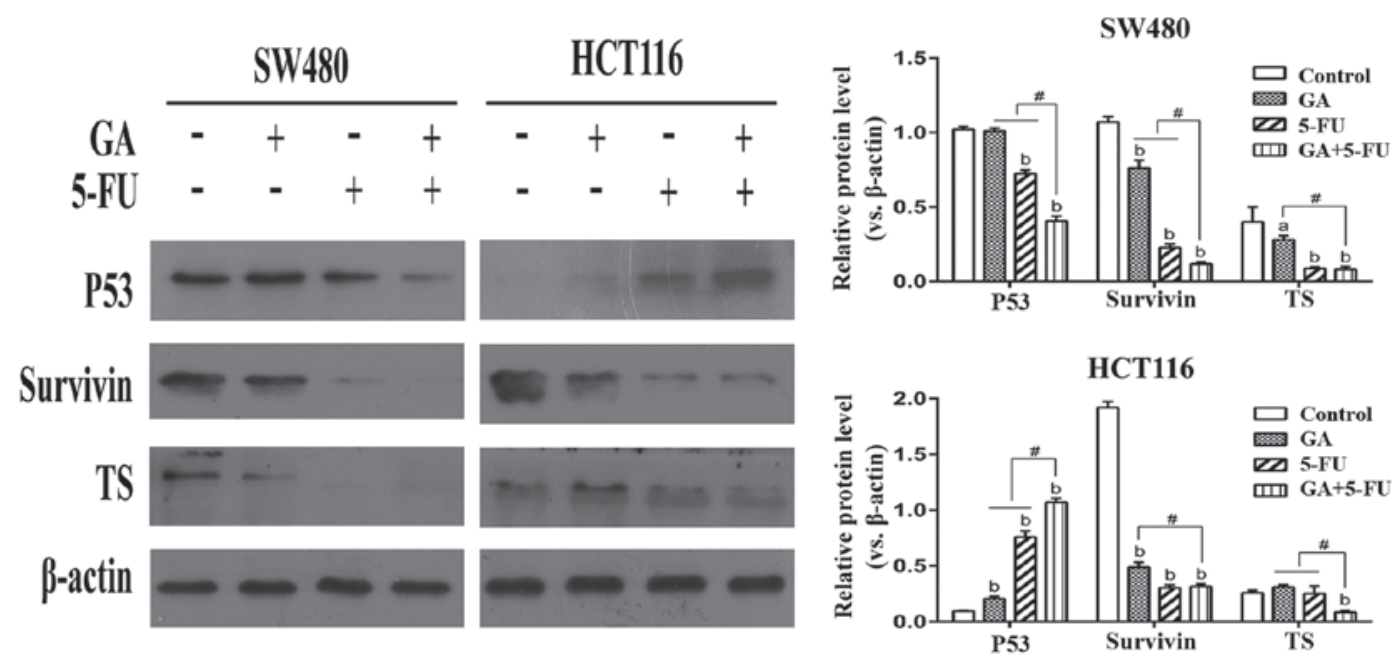

Figure 5. Changes of P53, survivin and TS protein levels. Cells were treated with GA (SW480, 0.75 $\mu \mathrm{M}$; HCT116, $1 \mu \mathrm{M}), 5$-FU (SW480, $122.14 \mu \mathrm{M}$; HCT116, $18.43 \mu \mathrm{M})$ or $\mathrm{GA}+5-\mathrm{FU}$ for $48 \mathrm{~h}$. Untreated cells were used as controls. ${ }^{\mathrm{a}} \mathrm{P}<0.05$ and ${ }^{\mathrm{b}} \mathrm{P}<0.01$ vs. the control. ${ }^{*} \mathrm{P}<0.01$. All assays were run in triplicate. 5 -FU, 5-fluorouracil; GA, gambogic acid.

survivin protein levels $(\mathrm{P}<0.01)$. GA alone decreased survivin and TS protein levels in SW480 cells $(\mathrm{P}<0.05)$; GA alone increased P53 protein levels and decreased survivin protein levels in HCT116 cells $(\mathrm{P}<0.01)$.

In comparison with 5-FU or GA alone, 5-FU+GA further decreased P53, survivin and TS protein levels in SW480 cells, and further decreased survivin and TS protein levels in HCT116 cells $(\mathrm{P}<0.01)$. P53 protein levels in HCT116 cells were increased to a greater extent by $5-\mathrm{FU}+\mathrm{GA}$ than by either 5-FU or GA alone ( $\mathrm{P}<0.01$; Fig. 5).

\section{Discussion}

GA is a novel anticancer drug whose mechanisms have not been fully explored. Wang et al (11) found that 5-FU and GA have synergistic effects in gastric cancer, both in vitro and in vivo; the proposed mechanism involved TS, dihydropyrimidine dehydrogenase and orotate phosphoribosyltransferase regulation, elevated caspase-3 and poly (ADP-ribose) polymerase cleavage activity, and a decreased Bcl-2/Bax ratio.

In the present study, it was found that GA potentiated the cytotoxicity of 5-FU to SW480 and HCT116 cells in a concentration-dependent manner. 5-FU and GA together had synergistic effects, and could further induce apoptosis. The synergism was also found in the regulation of P53, survivin and TS, at the gene and protein levels. Moreover, the combination of 5-FU and GA did not increase cytotoxicity to normal cells, indicating that the combination was not only effective, but also safe.

P53 is the most frequently mutated gene in human cancers (32), with mutations occurring in $40-50 \%$ of CRC patients (33). Mutant P53 not only loses tumor suppressive functions of the wild-type protein, but also gains new oncogenic activities, including promotion of growth, angiogenesis and metastasis, a change described as gain-of-function $(34,35)$. A previous study has shown that patients with CRC and mutant P53 have increased chemoresistance and poorer prognosis compared with those harboring wild-type P53 protein (36).

The two CRC cell lines assessed in the present study have different P53 types: SW480 has mutant P53 (37) while HCT116 has wild-type (38). The results demonstrated that HCT116 cells were more sensitive to 5-FU than were SW480 cells; the $\mathrm{IC}_{50}$ of 5-FU alone was $122.14 \mu \mathrm{M}$ for SW480, nearly 7-fold that obtained for HCT116 cells $(18.43 \mu \mathrm{M})$. This important difference in sensitivity may partly result from their P53 types, as mutant P53 is associated with chemoresistance (36). 
When 5-FU was combined with GA, both types of cell exhibited enhanced sensitivity and the synergistic effects on SW480 were more pronounced. When combined with $0.25 \mu \mathrm{M} \mathrm{GA}$, the $\mathrm{IC}_{50}$ of 5-FU was only $8.11 \mu \mathrm{M}$, indicating a 15 -fold reduction compared with the value obtained with 5 -FU alone. The $\mathrm{IC}_{50}$ decreased in accordance with increasing GA concentration in the combination. When combined with GA, SW480 cells were almost as sensitive to 5-FU as HCT116 cells were. Therefore, $\mathrm{GA}$ is able to reduce the therapeutically required dose of 5-FU, especially for SW480 cells.

The results of the present study showed that GA or 5-FU alone decreased SW480 mutant P53 mRNA and protein levels, and the combination resulted in more pronounced effects. In HCT116 cells, the combination of 5-FU and GA further increased wild-type P53 protein levels but decreased P53 mRNA expression. The decreased gene expression in HCT116 might be associated with negative-feedback inhibition.

P53 and survivin are both closely associated with apoptosis: Wild-type P53 induces apoptosis (20) while mutant P53 and survivin inhibit apoptosis $(22,34)$. The results of the present study indicate that the combination of 5-FU and GA induced apoptosis more strongly than did either monotherapy, with regulation of P53 and survivin also being observed, suggesting that P53 and survivin-related apoptosis might be involved in the synergistic anticancer effect.

TS plays an important role in 5-FU metabolism and it is an important target of 5-FU chemotherapy (25). In the present study, combined 5-FU and GA treatment further decreased the mRNA and protein expression of TS, suggesting TS was also involved in the synergistic anticancer effect.

High expression levels of survivin and TS are associated with chemoresistance $(24,28)$. In the present study, it was found that combined 5-FU and GA treatment further decreased the RNA and protein levels of survivin and TS compared with either monotherapy, consistent with improved chemoresistance and enhanced anticancer effects.

Overall, these findings demonstrate that GA potentiates the chemosensitivity of CRC cells to 5-FU without increasing the cytotoxicity to normal cells. Thus, this combination might provide a promising treatment for patients with CRC. Future studies are essential to evaluate this combination in animal models and explore the underlying mechanisms.

\section{Acknowledgements}

This study was supported by a grant from the National Natural Science Foundation of China (grant no. 81272556). The authors thank MedSci (Shanghai, China) for English editing.

\section{References}

1. Torre LA, Bray F, Siegel RL, Ferlay J, Lortet-Tieulent J and Jemal A: Global cancer statistics, 2012. CA Cancer J Clin 65: 87-108, 2015.

2. Chen W, Zheng R, Zeng H, Zhang S and He J: Annual report on status of cancer in China, 2011. Chin J Cancer Res 27: 2-12, 2015

3. Akgül Ö, Çetinkaya E, Ersöz Ş and Tez M: Role of surgery in colorectal cancer liver metastases. World J Gastroenterol 20 : 6113-6122, 2014

4. Gustavsson B, Carlsson G, Machover D, Petrelli N, Roth A, Schmoll HJ, Tveit KM and Gibson F: A review of the evolution of systemic chemotherapy in the management of colorectal cancer. Clin Colorectal Cancer 14: 1-10, 2015
5. André T, Iveson T, Labianca R, Meyerhardt JA, Souglakos I, Yoshino T, Paul J, Sobrero A, Taieb J, Shields AF, et al: The IDEA (international duration evaluation of adjuvant chemotherapy) collaboration: Prospective combined analysis of Phase III trials investigating duration of adjuvant therapy with the FOLFOX (FOLFOX4 or modified FOLFOX6) or XELOX (3 versus 6 months) regimen for patients with stage III colon cancer: Trial design and current status. Curr Colorectal Cancer Rep 9: 261-269, 2013.

6. Kim SA, Kim I, Yoon SK, Lee EK and Kuh HJ: Indirect modulation of sensitivity to 5-fluorouracil by microRNA-96 in human colorectal cancer cells. Arch Pharm Res 38: 239-248, 2015.

7. Thirion P, Michiels S, Pignon JP, Buyse M, Braud AC, Carlson RW, O'Connell M, Sargent P and Piedbois P; Meta-Analysis Group in Cancer: Modulation of fluorouracil by leucovorin in patients with advanced colorectal cancer: An updated meta-analysis. J Clin Oncol 23: 1337-1338, 2004.

8. André T, Louvet C, Maindrault-Goebel F, Couteau C, Mabro M, Lotz JP, Gilles-Amar V, Krulik M, Carola E, Izrael V and de Gramont A: CPT-11 (irinotecan) addition to bimonthly, high-dose leucovorin and bolus and continuous-infusion 5-fluorouracil (FOLFIRI) for pretreated metastatic colorectal cancer. GERCOR. Eur J Cancer 35: 1343-1347, 1999.

9. de Gramont A, Figer A, Seymour M, Homerin M, Hmissi A, Cassidy J, Boni C, Cortes-Funes H, Cervantes A, Freyer G, et al: Leucovorin and fluorouracil with or without oxaliplatin as first-line treatment in advanced colorectal cancer. J Clin Oncol 18: 2938-2947, 2000.

10. Su J, Cheng H, Zhang D, Wang M, Xie C, Hu Y, Chang HC and $\mathrm{Li}$ Q: Synergistic effects of 5-fluorouracil and gambogenic acid on A549 cells: Activation of cell death caused by apoptotic and necroptotic mechanisms via the ROS-mitochondria pathway. Biol Pharm Bull 37: 1259-1268, 2014.

11. Wang J, Liu W, Zhao Q, Qi Q, Lu N, Yang Y, Nei FF, Rong JJ, You QD and Guo QL: Synergistic effect of 5-fluorouracil with gambogic acid on BGC-823 human gastric carcinoma. Toxicology 256: 135-140, 2009.

12. Suzuki R, Kang Y, Li X, Roife D, Zhang R and Fleming JB: Genistein potentiates the antitumor effect of 5-Fluorouracil by inducing apoptosis and autophagy in human pancreatic cancer cells. Anticancer Res 34: 4685-4692, 2014.

13. Qi Q, You Q, Gu H, Zhao L, Liu W, Lu N and Guo Q: Studies on the toxicity of gambogic acid in rats. J Ethnopharmacol 117: 433-438, 2008

14. Xu J, Zhou M, Ouyang J, Wang J, Zhang Q, Xu Y, Xu Y, Zhang Q, Xu X and Zeng H: Gambogic acid induces mitochondria-dependent apoptosis by modulation of Bcl-2 and Bax in mantle cell lymphoma JeKo-1 cells. Chin J Cancer Res 25: 183-191, 2013.

15. Duan D, Zhang B, Yao J, Liu Y, Sun J, Ge C, Peng S and Fang J: Gambogic acid induces apoptosis in hepatocellular carcinoma SMMC-7721 cells by targeting cytosolic thioredoxin reductase. Free Radic Biol Med 69: 15-25, 2014.

16. Zhao W, Zhou SF, Zhang ZP, Xu GP, Li XB and Yan JL: Gambogic acid inhibits the growth of osteosarcoma cells in vitro by inducing apoptosis and cell cycle arrest. Oncol Rep 25: 1289-1295, 2011.

17. Lu N, Hui H, Yang H, Zhao K, Chen Y, You QD and Guo QL: Gambogic acid inhibits angiogenesis through inhibiting PHD2-VHL-HIF-1 $\alpha$ pathway. Eur J Pharm Sci 49: 220-226, 2013.

18. Qi Q, Lu N, Li C, Zhao J, Liu W, You Q and Guo Q: Involvement of RECK in gambogic acid induced anti-invasive effect in A549 human lung carcinoma cells. Mol Carcinog 54 (Suppl 1): E13-E25, 2015

19. Vogelstein B, Lane D and Levine AJ: Surfing the p53 network. Nature 408: 307-310, 2000.

20. Vousden KH and Prives C: Blinded by the light: The growing complexity of p53. Cell 137: 413-431, 2009.

21. Wang S, Wang L, Chen M and Wang Y: Gambogic acid sensitizes resistant breast cancer cells to doxorubicin through inhibiting P-glycoprotein and suppressing survivin expression. Chem Biol Interact 235: 76-84, 2015.

22. Ambrosini G, Adida C and Altieri DC: A novel anti-apoptosis gene, survivin, expressed in cancer and lymphoma. Nat Med 3: 917-921, 1997.

23. Sarela AI, Macadam RC, Farmery SM, Markham AF and Guillou PJ: Expression of the antiapoptosis gene, survivin, predicts death from recurrent colorectal carcinoma. Gut 46: 645-650, 2000 
24. Lee MR, Ji SY, Mia-Jan K and Cho MY: Chemoresistance of CD133(+) colon cancer may be related with increased survivin expression. Biochem Biophys Res Commun 463: 229-234, 2015.

25. Sun Z, Zhou N, Han Q, Zhao L, Bai C, Chen Y, Zhou J and Zhao RC: MicroRNA-197 influences 5-fluorouracil resistance via thymidylate synthase in colorectal cancer. Clin Transl Oncol 17: $876-883,2015$.

26. Rahman L, Voeller D, Rahman M, Lipkowitz S, Allegra C, Barrett JC, Kaye FJ and Zajac-Kaye M: Thymidylate synthase as an oncogene: A novel role for an essential DNA synthesis enzyme. Cancer Cell 5: 341-351, 2004.

27. Noordhuis P, Holwerda U, Van der Wilt CL, Van Groeningen CJ Smid K, Meijer S, Pinedo HM and Peters GJ: 5-Fluorouracil incorporation into RNA and DNA in relation to thymidylate synthase inhibition of human colorectal cancers. Ann Oncol 15 1025-1032, 2004.

28. Nakamura A, Nakajima G, Okuyama R, Kuramochi H Kondoh Y, Kanemura T, Takechi T, Yamamoto $M$ and Hayashi K: Enhancement of 5-fluorouracil-induced cytotoxicity by leucovorin in 5-fluorouracil-resistant gastric cancer cells with upregulated expression of thymidylate synthase. Gastric Cancer 17: 188-195, 2014.

29. Subbarayan PR, Lee K and Ardalan B: Arsenic trioxide suppresses thymidylate synthase in 5-FU-resistant colorectal cancer cell line HT29 in vitro Re-sensitizing cells to 5-FU. Anticancer Res 30: 1157-1162, 2010.
30. Chou TC: Drug combination studies and their synergy quantification using the Chou-Talalay method. Cancer Res 70: 440-446, 2010.

31. Livak KJ and Schmittgen TD: Analysis of relative gene expression data using real-time quantitative PCR and the 2(-Delta Delta C(T)) Method. Methods 25: 402-408, 2001.

32. Kandoth C, McLellan MD, Vandin F, Ye K, Niu B, Lu C, Xie M, Zhang Q, McMichael JF, Wyczalkowski MA, et al: Mutational landscape and significance across 12 major cancer types. Nature 502: 333-339, 2013.

33. Takayama T, Miyanishi K, Hayashi T, Sato Y and Niitsu Y: Colorectal cancer: Genetics of development and metastasis. J Gastroenterol 41: 185-192, 2006.

34. Muller PA and Vousden KH: p53 mutations in cancer. Nat Cell Biol 15: 2-8, 2013.

35. Freed-Pastor WA and Prives C: Mutant p53: One name, many proteins. Genes Dev 26: 1268-1286, 2012.

36. Iacopetta B: TP53 mutation in colorectal cancer. Hum Mutat 21 271-276, 2003.

37. Rochette PJ, Bastien N, Lavoie J, Guérin SL and Drouin R SW480, a p53 double-mutant cell line retainsproficiency for some p53 functions. J Mol Biol 352: 44-57, 2005.

38. Yang WL, Perillo W, Liou D, Marambaud P and Wang P: AMPK Inhibitor compound c suppresses cell proliferation by induction of apoptosis and autophagy in human colorectal cancer cells. J Surg Oncol 106: 680-688, 2012. 